\title{
Students' attitudes toward ESP course at university level
}

\author{
Maja R. Ivančević Otanjac \\ University of Belgrade - Faculty of Special Education and Rehabilitation, Belgrade, Serbia
}

Introduction. English for Specific Purposes (ESP) at universities has a challenging goal of meeting the needs of usually large and heterogeneous groups of students. Objective. The aim of this study was to examine students' attitudes toward the ESP course, acquired knowledge, and course materials at the Faculty of Special Education and Rehabilitation, University of Belgrade. In addition, the study examined the possible influence of students' general English proficiency on the tested variables. Methods. An online questionnaire was used to collect data from 75 students who completed the ESP course in 2020 or 2021. Their general English proficiency was assessed by an online general English test. Results. The results showed that most students were satisfied with the acquired professional English language knowledge and available course materials and that their attitudes toward the completed ESP course were not influenced by their general English proficiency. Conclusion. These results are encouraging since they indicate overall student satisfaction with the ESP university course taught to a large class. education

Keywords: ESP, general English, course materials, technical vocabulary, special

\section{Introduction}

Unlike English for General Purposes (EGP), which aims to improve students' general English proficiency, the main aim of English for Specific Purposes (ESP) is to meet learners' specific needs by focusing on language activities relevant to specific topics, disciplines, or occupations (Dudley-Evans \& St John, 1998). Target learners of ESP courses are usually adults, professionals, or university students who are expected to have some previous general English knowledge (Ignjačević, 2008). The relationship between teachers and students in ESP has been described as "different but complementary", where teachers are language specialists with pedagogical skills and students have some

* Correspondence: Maja Ivančević Otanjac, majaotanjac@fasper.bg.ac.rs 
professional knowledge in their mother tongue (Sarmento et al., 2018). However, it is very difficult to make generalized assumptions regarding their knowledge of English. There are indications that ESP students usually have intermediate or advanced knowledge of English (Liu \& Berger, 2015), although, nowadays, there are many ESP courses designed for pre-intermediate and intermediate English language learners (Day \& Krzanowski, 2011).

Foreign language learning at university level aims to provide students with professionally oriented language knowledge and skills through carefully designed course and content (Đorović, 2011). Course materials used in ESP also significantly differ from those used in EGP. Their design largely depends on the needs analysis as one of the key principles in ESP (Richards, 2001). This means that an ESP coursebook at university level should be designed according to students' needs, i.e., it should be related to the students' field of study, include informative texts, and focus on topic-related vocabulary and tasks. Some authors (Blagojević, 2013; Glišović, 2014) emphasize the need and advantages of using teaching materials based on authentic language in ESP courses at university level (e.g., newspaper articles, original texts, video materials, etc.) with the aim to provide university students with "real-life" materials related to their field of study. Although authentic texts are considered crucial in teaching ESP by many language teachers, they can be too complex for students at different levels of linguistic competence, and should thus be carefully selected and based on both students' professional needs and their previous language knowledge (Blagojević, 2013). Since ESP classes at university level can be very large and heterogeneous in relation to students' general English proficiency, it is often needed to adapt or simplify such texts to meet the needs of all students in the class.

Selecting a syllabus framework is another important factor in designing an ESP course and is the basis of its instructional focus and content (Richards, 2001). Ideally, an ESP course should not only cover specific vocabulary, contexts, and topics relevant to students' needs and interests, but also provide opportunities for practicing general language skills. However, the reality is different in very large classes, where there is neither the time nor the opportunity to cover all of the above. With over 200 students in one class, the syllabus framework of the ESP course at the Faculty of Special Education and Rehabilitation (FASPER) in Belgrade can be described as predominantly lexical (Ivančević Otanjac, 2014a), focusing on target vocabulary, or in this case technical vocabulary (words which are closely related to a subject area and which are relatively common in that specific area but not elsewhere (Nation, 2001). However, it should not be wrongly assumed that learning vocabulary in ESP means learning individual words out of context (Đurović \& Silaški, 2010). The context in which technical words occur, subject-related topics, and appropriate tasks and activities all have great influence on language acquisition and student motivation. As Manić and Vučo (2015) point out, student motivation 
to learn technical vocabulary increases when ESP course is related to the subject matter of other professional subjects. With regard to this, the ESP syllabus at FASPER could also be described as topical (organized around topics relevant to the students' field of study - in this case special education, different types of disabilities, impairments, available support, etc.), and task-based (organized around various tasks and activities the students will need to perform in English, e.g., reading authentic sources in English for the purpose of doing research in their field of study, writing papers in English, giving presentations, translating professional texts from English into their mother tongue, etc.). The importance of subject-related topics and vocabulary is emphasized by the fact that the final exam in this course assesses both technical vocabulary and general English knowledge, awarding equal number of points at both parts of the test. ESP vocabulary at university level should be considered equally important as general English as it enables university students to advance in their professional fields and do academic research (Mićić \& Sinadinović, 2013). The ESP course at FASPER sets a very challenging goal in attempting to meet the needs of a very large and heterogeneous group of students and provide them with adequate English language knowledge in the field of special education through authentic materials adapted to their general English skills.

With regard to all of the above, this study aimed to examine students' satisfaction with the acquired professional English language knowledge and available course materials. In addition, the research also tried to determine whether general English proficiency had a significant influence on students' attitudes toward the completed ESP course and grammar and vocabulary acquisition.

\section{Method}

The sample included 75 first and second-year students of Special Education and Rehabilitation at the University of Belgrade who completed the ESP course in June 2020 or 2021 . The participants were $19-25$ years of age $(M=20.56, S D=1.21)$. Gender distribution was uneven, with $71(94.7 \%)$ women and only four (5.3\%) men. Most participants (80\%) previously learned English in elementary and secondary school, 14.7\% had additional English language lessons either in a foreign language school or with a private teacher, while only 5.3\% had English only in elementary school. Also, most participants did not have difficulties in passing the final ESP exam at the end of their first year of study $(82.7 \%$ passed at their first attempt, $13.3 \%$ at the second attempt, only one student $[1.3 \%]$ at the third attempt, and there were two students $[2.7 \%]$ who did not pass the final exam by the end of the fourth exam term in September 2021).

The survey was conducted using the Questionnaire created in Google Forms and distributed online to over 400 students. Before completing the Questionnaire, the students were informed in written form that the survey was anonymous and that 
the answers would be used for the purpose of this study. With only 75 completed questionnaires, it can be said that the response rate was not particularly high (below $20 \%$ ). The first part of the Questionnaire was used to collect the demographic data, while the second part included four statements regarding the participants' attitudes toward the completed ESP course, acquired knowledge, and course materials. The participants had to rate each statement on a 5-point scale (from 1-strongly disagree to 5 -strongly agree). Data on the participants' general English proficiency was collected by the General English Test (Cambridge Assessment English, 2021) available online at https://www.cambridgeenglish.org/test-your-english/general-english/, which the students were asked to do before completing the Questionnaire.

Descriptive statistics methods were used in data processing. Spearman's correlation coefficient was used to examine the relationship between variables. One-way ANOVA was used to determine the possible influence of general English proficiency on the tested variables.

\section{Results and discussion}

Before completing the questionnaire, the participants were asked to do the General English Test in order to determine their proficiency level (A2-C2, according to the Common European Framework of Reference for Languages (Council of Europe, 2001). The results are presented in Chart 1.

\section{Chart 1}

Participants' general English proficiency level

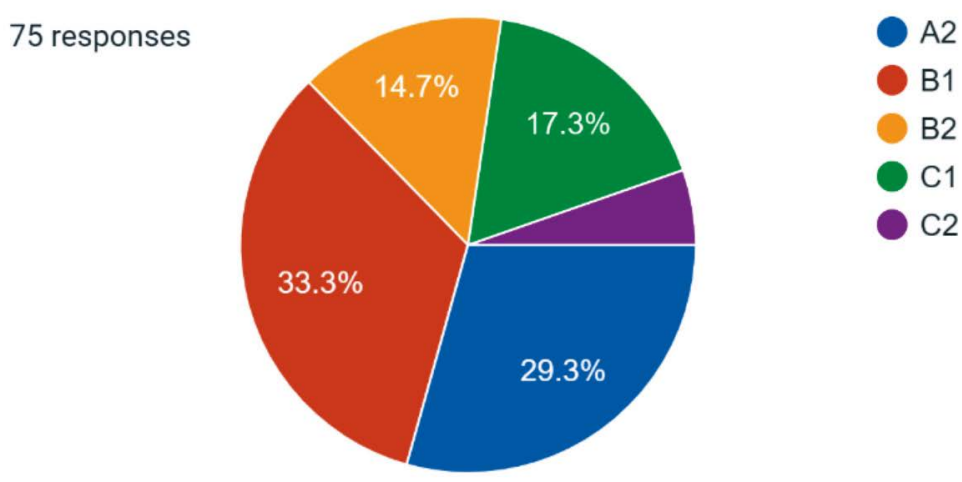

The results show that most participants were at $\mathrm{B} 1(33.3 \%)$ and $\mathrm{A} 2$ $(29.3 \%)$ levels. These results were not surprising since most participants had previously learned English only in elementary and secondary school (80\%), and since the expected proficiency level of first-year students at the beginning of the ESP course at FASPER is between pre-intermediate and intermediate (A2B1) (Ivančević Otanjac, 2014b). However, the remaining 37.4\% were students 
at B2 (14.7\%), C1 (17.3\%), and even C2 (5.4\%) level. While appropriacy, i.e., the appropriate task level which corresponds to students' competence, is one of the key factors in task-based language learning (Wilson, 1986), the group's heterogeneity makes it difficult to develop an ESP course which would equally satisfy the needs of all students. Similar findings were reported by Enesi, Vrapi, and Trifoni (2021) who examined the difficulties related to ESP students from the perspective of ESP teachers at three universities in Albania. They determined that one of the most prominent difficulties reported by ESP teachers was the fact that they had students of different proficiency levels in the same class. Class size is another hindering factor in developing a comprehensive ESP course for university students. In their research on difficulties in teaching ESP courses at Vietnam universities, Hoa and Mai (2016) point out that large classes significantly affect ESP teaching efficacy and student motivation, especially when students are not at the same proficiency level and when the activities are either too difficult or too easy for them.

The second part of the Questionnaire was used in this study to determine the participants' satisfaction with the acquired professional English language knowledge and available course materials in the field of special education. It included four statements (see Table 1). The participants were asked to rate each statement on a scale ranging from 1 (strongly disagree) to 5 (strongly agree). Mean scores, standard deviations and 99\% confidence intervals for each statement are shown in Table 1.

\section{Table 1}

Participants' attitudes toward grammar and vocabulary acquisition, ESP course, and course materials $(N=75)$

\begin{tabular}{lccc}
\hline Statements & $M$ & $S D$ & $99 \% C I$ \\
\hline $\begin{array}{l}\text { I had no difficulty in learning grammar in the ESP } \\
\text { course during my 1st year of study }\end{array}$ & 4.33 & 1.00 & $4.03-4.63$ \\
$\begin{array}{l}\text { I had no difficulty in learning technical vocabulary } \\
\text { in the ESP course during my 1 }\end{array}$ & 4.4 & 0.74 & $4.18-4.62$ \\
$\begin{array}{l}\text { I believe I managed to acquire adequate English } \\
\text { language knowledge in the field of special } \\
\text { education during my first year of study }\end{array}$ & 4.05 & 0.94 & $3.77-4.33$ \\
$\begin{array}{l}\text { The available course materials (coursebook, } \\
\text { additional exercises, presentations, videos, etc.) } \\
\text { were all I needed to prepare for my final exam }\end{array}$ & 4.83 & 0.38 & $4.72-4.94$ \\
\hline
\end{tabular}

The results show that the participants mainly had positive attitudes toward the completed ESP course and grammar and vocabulary acquisition with lower bounds of $99 \%$ confidence intervals consistently far above the theoretical mean of a 5-point scale. All participants were satisfied with the available course materials as $82.7 \%$ rated this statement with 5 (strongly agree), 
and the remaining $17.3 \%$ with 4 (agree). A moderately positive correlation was determined between the acquisition of grammar and technical vocabulary $(r$ $=.61, p<.001)$ and between the participants' satisfaction with the acquired knowledge and available course materials $\left(r_{s}=.43, p<.001\right)$.

Several other studies reported similar results regarding students' overall positive attitudes toward ESP courses at universities, pointing out the importance and advantages of ESP curriculum for university students. Martinović and Poljaković (2010) examined attitudes of 149 first year students in the fields of Humanities and Social Sciences at the University of Zadar. They determined that students mainly had positive attitudes toward the teacher, English, and learning English despite the perceived lack of enthusiasm and effort in their English language classes. In their study on the analysis of students' motivation in choosing a foreign language course at non-affiliated university departments, Cvetković and Gorgiev (2019) analyzed a sample of 27 undergraduate and four master students at the Faculty of Philosophy, University of Niš. Their results showed that the participants chose ESP mainly for practical reasons, i.e., to improve knowledge related to their field of study and apply their general English knowledge according to their general interests. The study conducted by Bekteshi and Xhaferi (2020) on a sample of 239 first and second-year students of Engineering faculties at the University of Mitrovica showed that the majority of the participants believed the ESP course for engineering students was a "must", and that the students generally benefited from the ESP classes. The authors also pointed out the need for careful selection and adaptation of teaching materials based on students' needs and deficiencies while learning professional English. Arnó-Macià, Aguilar-Pérez, and Tatzl (2020) examined the perceptions of engineering students at two European universities (in Spain and Austria). Their results showed an overall satisfaction of engineering students with the ESP courses in relation to their expectations, learning objectives, perceived development of different skills, and evaluation of the ESP course as preparation for academic and professional communication.

This study also aimed to examine whether the participants' general English proficiency had a significant influence on three tested variables (grammar and technical vocabulary acquisition, and satisfaction with the ESP course). The results of one-way ANOVA are presented in Table 2.

The results show that there was no statistically significant difference in the participants' satisfaction with the ESP course in relation to their general English proficiency $(p>.05)$. Furthermore, the fact that most participants (82.7\%) passed their final exam at first attempt, shows that the students were mainly successful in the ESP course regardless of their general English proficiency. Similar results were reported by Chostelidou (2011) who analyzed the impact of general English on the effectiveness of ESP teaching intervention in a sample of 286 Business English university students in Northern Greece. 
The results showed that ESP teaching intervention in the experimental group was successful and that, irrespective of general English proficiency, the experimental group outperformed the control group (which was not exposed to the ESP teaching intervention) in subject-related knowledge and skills. On the other hand, Maasum (2011) examined the role of general English in ESP success at Iranian universities and determined a strong positive correlation between the students' general English knowledge and their ESP achievement. However, as the author points out, the relationship between general English and ESP depends on many factors most of which were not controlled in the study.

\section{Table 2}

Influence of general English proficiency on examined variables

\begin{tabular}{|c|c|c|c|c|c|c|}
\hline \multirow{2}{*}{ Variables } & \multicolumn{4}{|c|}{ General English proficiency $M(S D)$} & \multirow{2}{*}{$F(3,67)$} & \multirow[b]{2}{*}{$p$} \\
\hline & $A 2$ & $B 1$ & $B 2$ & $C 1$ & & \\
\hline Grammar acquisition & $3.73(1.12)$ & $4.36(0.86)$ & $4.91(0.30)$ & $4.62(1.12)$ & 4.71 & .005 \\
\hline $\begin{array}{l}\text { Technical vocabulary } \\
\text { acquisition }\end{array}$ & $3.95(0.90)$ & $4.36(0.64)$ & $4.64(0.50)$ & $4.85(0.38)$ & 5.43 & .002 \\
\hline $\begin{array}{l}\text { Satisfaction with ESP } \\
\text { course }\end{array}$ & $3.68(1.04)$ & $4.04(1.02)$ & $4.18(0.87)$ & $4.46(0.52)$ & 2.04 & .12 \\
\hline
\end{tabular}

Table 2 shows that general English proficiency had a significant influence on the participants' attitudes toward the acquisition of grammar $[F(3,67)=4.71$, $p=.005]$ and technical vocabulary $[F(3,67)=5.43, p=.002]$. These results were not surprising since it was expected that students at higher general English level would acquire grammar and vocabulary more easily in this ESP course.

\section{Conclusion and limitations}

This study showed that Special Education and Rehabilitation students at the University of Belgrade had mainly positive attitudes toward the completed ESP course and available course materials. Also, the research determined that general English proficiency had a significant influence on the acquisition of grammar and technical vocabulary, i.e., that students at higher general English levels had fewer difficulties in grammar and vocabulary acquisition. On the other hand, their general satisfaction with the ESP course and their final exam success were not influenced by their general English competence. However, it should be noted that the response rate of the sample was not very high since the online Questionnaire was distributed to over 400 students and completed by 75 . Another limitation of this study could also be the assumption that the students who completed the Questionnaire were generally better in English, and thus had more positive attitudes and fewer difficulties, than those who decided not to participate. 


\section{References}

Arnó-Macià, E., Aguilar-Pérez, M., \& Tatzl, D. (2020). Engineering students’ perceptions of the role of ESP courses in internationalized universities. English for Specific Purposes, 58, 58-74. https://doi.org/10.1016/j.esp.2019.12.001

Bekteshi, E., \& Xhaferi, B. (2020). An analysis of English for specific purposes among university students. Educational Process: International Journal, 9(2), 90-102. http://dx.doi.org/10.22521/edupij.2020.92.2

Blagojević, S. (2013). Original texts as authentic ESP teaching material - the case of philosophy. ESP Today, 1(1), 113-126.

Cambridge Assessment English. (2021, October 30). General English. Cambridge University Press \& Assessment. https://www.cambridgeenglish.org/test-yourenglish/general-english/

Chostelidou, D. (2011). Needs-based course design: The impact of general English knowledge on the effectiveness of an ESP teaching intervention. Procedia Social and Behavioral Sciences, 15, 403-409.

Council of Europe. (2001). Common European Framework of Reference for Languages: Learning, Teaching, Assessment. Cambridge University Press.

Cvetković, T., \& Gorgiev, B. (2019). Analiza motivacije studenata prilikom izbora stranog jezika na nematičnim departmanima [Analysis of students' motivation in choosing a foreign language course at non-affiliated departments]. Reči, 12, 54-68.

Day, J., \& Krzanowski, M. (2011). Teaching English for specific purposes: An introduction. Cambridge University Press.

Dudley-Evans, T., \& St John, M. J. (1998). Developments in English for specific purposes: A multi-disciplinary approach. Cambridge University Press.

Đorović, D. (2011). Veštine čitanja i razvijanja vokabulara za specifične potrebe u nastavi jezika struke na univerzitetskom nivou [Reading and vocabulary development skills in teaching language for specific purposes at university level]. Teme, 35(3), 819-836.

Đurović, T., \& Silaški, N. (2010). Teaching genre-specific grammar and lexis at tertiary level: The case of economics students. Journal of Linguistic Studies, 3(1), 165-176.

Enesi, M., Vrapi, F., \& Trifoni, A. (2021). Challenges of teaching and learning English language for ESP courses. Journal of Educational and Social Research, 11(4), 213226. https://doi.org/10.36941/jesr-2021-0090

Glišović, I. (2014). Autentičan jezik u nastavi stranih jezika na nefilološkim fakultetima [Authentic language in foreign language teaching at non-philological departments]. In B. Dimitrijević (Ed.), Jezik, književnost i kultura [Language, literature and culture] (pp. 236-246). Univerzitet u Nišu - Filozofski fakultet.

Hoa, N. T. T., \& Mai, P. T. T. (2016). Difficulties in teaching English for specific purposes: Empirical study at Vietnam universities. Higher Education Studies, 6(2), 154-161. http://dx.doi.org/10.5539/hes.v6n2p154

Ignjačević, A. (2008). Specifičnosti nastave stranog jezika struke [Teaching foreign language for specific purposes]. Nastava $i$ vaspitanje, 57(2), 150-156.

Ivančević Otanjac, M. (2014a). The development of English for specific purposes syllabus for first-year students of special education and rehabilitation. Specijalna edukacija $i$ rehabilitacija, 13(1), 107-115. https://doi.org/10.5937/specedreh13-5902

Ivančević Otanjac, M. (2014b). Teaching English grammar to students of special education and rehabilitation. The Journal of Teaching English for Specific and Academic Purposes, 2(2), 229-234.

Liu, J., \& Berger, C. M. (2015). TESOL: A guide. Bloomsbury Academic. 
Manić, D., \& Vučo, J. (2015). Unapređivanje nastave stranog jezika struke u srednjim stručnim školama - CLIL i TBLT iskustva u projektu PETALL [Improving ESP in vocational schools - CLIL and TBLT experiences in PETALL project]. Primenjena lingvistika, 16, 79-88. https://doi.org/10.18485/primling.2015.16.6

Martinović, A., \& Poljaković, I. (2010). Attitudes toward ESP among university students. Fluminensia, 22(2), 145-161.

Maasum, S. M. H. (2011). The role of general background in the success of ESP courses: Case study in Iranian universities. Literacy Information and Computer Education Journal (LICEJ), 2(3), 424-433.

Mićić, S., \& Sinadinović, D. (2013). Teaching vocabulary to Medical English students theory and practice. Primenjena lingvistika, 14, 39-49.

Nation, I. S. P. (2001). Learning vocabulary in another language. Cambridge University Press.

Richards, J. C. (2001). Curriculum development in language learning. Cambridge University Press.

Sarmento, S., Viana, V., \& Bocorny, A. E. (2018). English for specific purposes (ESP). TESOL Press.

Wilson, J. (1986). Task-based language learning. In C. J. Brumfit, \& D. Harper (Eds.), ESP for the university (pp. 27-64). Pergamon Press \& The British Council.

\title{
Stavovi studenata prema nastavi engleskog jezika struke na fakultetima
}

\author{
Maja R. Ivančević Otanjac \\ Univerzitet u Beogradu - Fakultet za specijalnu edukaciju i rehabilitaciju, Beograd, Srbija
}

Uvod: Nastava engleskog jezika struke na fakultetima ima za cilj da zadovolji potrebe obično velikih i heterogenih grupa studenata. Cilj: Cilj ovog rada je da ispita stavove studenata Fakulteta za specijalnu edukaciju i rehabilitaciju Univerziteta u Beogradu, prema nastavi engleskog jezika struke, stečenom znanju engleskog jezika iz oblasti specijalne edukacije i nastavnim materijalima. Pored toga, rad ispituje i mogući uticaj opšteg engleskog jezika na pomenute varijable. Metode: Za prikupljanje podataka je korišćen onlajn upitnik koji je popunilo 75 studenata koji su slušali Engleski jezik tokom 2020. i 2021. godine. Njihovo znanje opšteg engleskog jezika utvrđeno je dostupnim onlajn testom. Rezultati; Rezultati pokazuju da je većina studenata zadovoljna stečenim znanjem engleskog jezika iz oblasti specijalne edukacije i nastavnim materijalima, kao i da nivo znanja opšteg engleskog jezika nije bitno uticao na njihove stavove prema nastavi engleskog jezika struke. Zaključak: Dobijeni rezultati su ohrabrujući jer ukazuju na zadovoljstvo studenata nastavom engleskog jezika struke koja se izvodi u velikim grupama na fakultetu.

Ključne reči: engleski jezik struke, opšti engleski, nastavni materijal, stručni vokabular, specijalna edukacija 